\section{High Relative Humidity Increases Yield, Harvest Index, Flowering, and Gynophore Growth of Hydroponically Grown Peanut Plants}

\author{
D.G. Mortley ${ }^{1}$, C.K. Bonsi ${ }^{2}$, P.A. Loretan ${ }^{2,4}$, W.A. Hill ${ }^{2}$, and \\ C.E. Morris ${ }^{3}$ \\ Center for Food and Environmental Systems for Human Exploration of Space, \\ Department of Agricultural Sciences, Tuskegee University, Tuskegee, \\ AL 36088
}

\begin{abstract}
Additional index words. Arachis hypogaea, nutrient film technique, hydroponics, fruit growth
\end{abstract}

\begin{abstract}
Growth chamber experiments were conducted to study the physiological and growth response of peanut (Arachis hypogaea L.) to $50 \%$ and $85 \%$ relative humidity $(\mathrm{RH})$. The objective was to determine the effects of RH on pod and seed yield, harvest index, and flowering of peanut grown by the nutrient film technique (NFT). 'Georgia Red' peanut plants $(14$ days old) were planted into growth channels $(0.15 \times 0.15 \times 1.2 \mathrm{~m})$. Plants were spaced $25 \mathrm{~cm}$ apart with $15 \mathrm{~cm}$ between channels. A modified half-Hoagland solution with an additional 2 mм Ca was used. Solution pH was maintained between 6.4 and 6.7, and electrical conductivity (EC) ranged between 1100 and $1200 \mu \mathrm{S} \cdot \mathrm{cm}^{-1}$. Temperature regimes of $28 / 22{ }^{\circ} \mathrm{C}$ were maintained during the light/dark periods ( 12 hours each) with photosynthetic photon flux $(P P F)$ at canopy level of $500 \mu \mathrm{mol} \cdot \mathrm{m}^{-2} \cdot \mathrm{s}^{-1}$. Foliage and pod fresh and dry weights, total seed yield, harvest index $(\mathrm{HI})$, and seed maturity were greater at high than at low RH. Plants grown at $85 \% \mathrm{RH}$ had greater total and individual leaflet area and stomatal conductance, flowered 3 days earlier and had a greater number of flowers reaching anthesis. Gynophores grew more rapidly at $85 \%$ than at $50 \% \mathrm{RH}$.
\end{abstract}

Several studies have documented the positive effects of relative humidity $(\mathrm{RH})$ on growth of plants, including lettuce (Lactuca sativa $\mathrm{L}$.) (Tibbitts and Bottenburg, 1976), wheat (Triticum aestivum L.), sugarbeet (Beta vulgaris L.) and kale (Brassica oleracea L.) (Ford and Thorne, 1973), red kidney bean (Phaseolus vulgaris L.) (O'Leary and Knecht, 1970), pearl millet (Pennisetum typhoides S.) (Black and Squire, 1979), potato (Solanum tuberosum L.) (Wheeler et al., 1989), and sweetpotato [Ipomoea batatas (L.) Lam.] (Mortley et al., 1994). However, there are few studies on the effects of RH on growth and yield of peanut. Lee et al. (1972) grew peanut under $50 \%$ or $95 \% \mathrm{RH}$ initially, then switched treatments after $50 \mathrm{~d}$ (low-RH plants were shifted to high RH and

Received for publication 21 Dec. 1998. Accepted for publication 7 May 1999. Contribution No. 308 of the George Washington Carver Agricultural Experiment Station, Tuskegee Univ. This research was supported by funds from the U.S. National Aeronautics and Space Administration (Grant No. NAG100024) and U.S. Dept. of Agriculture (Grant No. ALX-SP-1). We wish to thank Dr. Bill Branch of the Univ. of Georgia Experiment Station for providing the seeds. The cost of publishing this paper was defrayed in part by the payment of page charges. Under postal regulations, this paper therefore must be hereby marked advertisement solely to indicate this fact.

${ }^{1}$ Research Associate Professor.

${ }^{2}$ Professor.

${ }^{3}$ Associate Professor.

${ }^{4}$ Deceased 17 Oct. 1998. vice versa). They reported that plants grown under high $\mathrm{RH}$ later in the season produced more flowers and set a larger percentage of pegs than those grown under low RH.

Research on growth responses of food crops under controlled-environment conditions is currently being conducted by the National Aeronautics and Space Administration (NASA) for extended manned space missions through its Advanced Life-Support (ALS) program. Peanut is among several candidate crops for potential use in ALS because of its high edible oil $(44 \%$ to $56 \%)$ and high protein The objective of this study was to determine the effects of RH on pod and seed yield, harvest index, and flowering of peanut grown in NFT. Information gained from this study will add to NASA's overall objective of improving food production for extended space missions.

\section{Materials and Methods}

Two studies were conducted with two relative humidity (RH) treatments arranged in a randomized block design with two replications (= blocks) and 24 plants in each repetition. Two reach-in growth chambers (EGC-18 Environmental Growth Chambers, Chagrin Falls, Ohio) with $1.39 \mathrm{~m}^{2}$ each of growing area were used.

Seeding. Seeds were planted in moist Jiffy Mix (Geo J. Ball, Batavia, Ill.) media in TLC transplant flats (TLC Polyform, Plymouth, content (22\% to $30 \%$ ) (Davidson et al., 1982).
Minn.). Trays were placed in a growth chamber at $28^{\circ} \mathrm{C}$ light $/ 22^{\circ} \mathrm{C}$ dark, a $12 / 12$-h photoperiod, and a constant relative humidity of $70 \%$. Seeds were watered as needed, and seedlings were grown for $\approx 2$ weeks.

Transplanting. Three peanut seedlings were transplanted into each of four NFT growing channels in each chamber. Before seedlings were transplanted, they were carefully removed from each transplant tray cell and excess medium was removed, ensuring that minimal damage was done to the plant root system. The roots of the plants were gently washed with running tap water to remove particles of the medium that adhered to the roots. Plants were placed into NFT growing channels $(0.15 \times$ $0.15 \times 1.2 \mathrm{~m}$ ) through small openings made 25 $\mathrm{cm}$ apart in a perforated PVC-1 grid. The cover was $0.32 \mathrm{~cm}$ thick with perforations $0.32 \mathrm{~cm}$ in diameter on $0.56-\mathrm{cm}$ centers, and facilitated the entry of the developing gynophores into the pod production zone.

Growth chamber conditions. Growth chambers were maintained at $50 \% \pm 4 \%$ or $85 \% \pm$ $3 \%$, respectively, for both light and dark periods, and RH was measured weekly with a model 3312-40 wet bulb/dry bulb psychrometer (Cole-Parmer Instrument Co., Chicago). Daily RH ranged between $50 \% \pm 4 \%$ and $85 \%$ $\pm 3 \%$. Temperature was maintained at $28{ }^{\circ} \mathrm{C}$ light $/ 22^{\circ} \mathrm{C}$ dark, with a photosynthetic photon flux $(P P F)$ of $500 \mu \mathrm{mol} \cdot \mathrm{m}^{-2} \cdot \mathrm{s}^{-1} \approx 20 \mathrm{~cm}$ above the canopy supplied by a mixture of $16215-\mathrm{W}$ cool-white fluorescent and $12100-\mathrm{W}$ incandescent lamps. Photoperiod was 12-h light/ 12-h dark.

Nutrient solution. A modified halfHoagland (Hoagland and Arnon, 1950) nutrient solution was used at the beginning of the experiment. At flowering, the Ca concentration was increased from 2 to $4 \mathrm{~mm}$ to enhance seed fill. Nutrient solution was supplied to the plants in each channel by a 30.4-L reservoir by means of in-line pumps (Little Giant model 2 P037; Tecumseh Product Co., Oklahoma City, Okla.). The nutrient solution was pumped continuously from each reservoir to the high end of each growth channel. A flow rate of 1 $\mathrm{L} \cdot \mathrm{min}^{-1}$ was maintained in each channel by using a control valve and a bypass line. Growth channels were oriented with a $1 \%$ slope to facilitate the return of the nutrient solution to the reservoir by gravity flow. The nutrient solution was replenished weekly with a more dilute solution (one-third Hoagland). Nutrient solution $\mathrm{pH}$ and electrical conductivity were monitored three times a week, and ranged between 6.4 and 6.7 and 1100 and $1200 \mu \mathrm{S} \cdot \mathrm{cm}^{-1}$, respectively.

Plant biomass measurements and harvest. At flowering, $\approx 18 \mathrm{~d}$ after transplanting (DAP), and at 4-d intervals thereafter, the total numbers of flowers reaching anthesis were counted and recorded. Twenty-four gynophores per treatment were selected at random at emergence, and the rate of elongation was determined. Length was measured at emergence and at 3-d intervals until each gynophore reached a hole in the perforated PVC-1 cover. Beginning 47 DAP and weekly thereafter until day 86 porometer measurements (LI-1600 
Steady State Porometer; LI-COR, Lincoln, Nebr.) were made on the second fully expanded leaf on the main stem. The plants were harvested $110 \mathrm{~d}$ after transplanting (124 d from seeding), at which time fresh weights of component plant parts were recorded. All fully expanded leaflets were removed from each plant, counted, and total leaflet area was determined using a LI-3100 leaf area meter. The leaflets were dried for $72 \mathrm{~h}$ at $70^{\circ} \mathrm{C}$. Pods were removed from each plant, counted, weighed, and dried at $35^{\circ} \mathrm{C}$ for $72 \mathrm{~h}$. After drying, seeds were removed from pods and categorized as mature or immature according to the technique of Rucker et al. (1994), and pods and seeds in each category were weighed.

The experiment was repeated, with $\mathrm{RH}$ treatments switched between chambers to minimize possible chamber effects. Data were combined by treatment and analyzed by $t$ test (paired comparison) with pairing done on the basis of the two growth chambers.

\section{Results and Discussion}

Plants grown under $85 \% \mathrm{RH}$ produced greater foliage and pod fresh and dry weights (Table 1). Total seed yield was $38 \%$ greater and the yield of mature seeds was $41 \%$ greater at $85 \%$ than at $50 \%$ RH. Harvest index also was higher for plants grown under $85 \% \mathrm{RH}$.

Total and individual leaflet area averaged $24 \%$ greater at $85 \% \mathrm{RH}$ than at $50 \% \mathrm{RH}$ (Table 2 ), but specific leaf area and the number of leaves per plant did not differ significantly. Leaves were $\approx 1{ }^{\circ} \mathrm{C}$ warmer $\left(0.6^{\circ} \mathrm{C}\right.$ above that of the air) and stomatal conductance was higher in plants grown at $85 \% \mathrm{RH}$.

Plants flowered $3 \mathrm{~d}$ earlier when grown under $85 \% \mathrm{RH}$, and the number of flowers reaching anthesis was markedly greater (Fig. 1). The peak rate of flowering occurred within

Table 1. Growth responses of peanut at two humidity levels.

\begin{tabular}{lccc}
\hline \hline & \multicolumn{2}{c}{$\mathrm{RH}(\%)$} & \\
\cline { 2 - 3 } Response & 50 & 85 & $P$ \\
\hline Fresh weight $\left(\mathrm{g} \cdot \mathrm{m}^{-2}\right)$ & & & \\
$\quad$ Foliage & 5900 & 7600 & 0.04 \\
$\quad$ Pods and seeds & 1700 & 2000 & 0.02 \\
Dry weight $\left(\mathrm{g} \cdot \mathrm{m}^{-2}\right)$ & & & \\
$\quad$ Foliage & 1000 & 1300 & 0.01 \\
Pods & 600 & 800 & 0.007 \\
$\quad$ Seeds $\left(\mathrm{g} \cdot \mathrm{m}^{-2}\right)$ & 427 & 588 & 0.002 \\
Harvest index $(\%)^{\mathrm{z}}$ & 28.6 & 31.0 & 0.001 \\
\hline
\end{tabular}

${ }^{2}$ Harvest index $=($ seed weight/total plant weight $) \times$ 100.

Table 2. Leaf responses of peanut at two humidity levels.

\begin{tabular}{|c|c|c|c|}
\hline \multirow[b]{2}{*}{ Response } & \multicolumn{2}{|c|}{$\mathrm{RH}(\%)$} & \multirow[b]{2}{*}{$P$} \\
\hline & 50 & 85 & \\
\hline \multicolumn{4}{|l|}{ Leaf area $\left(\mathrm{cm}^{2}\right)$} \\
\hline Total & 3444 & 4263 & 0.02 \\
\hline Per leaflet & 21.0 & 26.0 & 0.0003 \\
\hline $\operatorname{SLA}^{\mathrm{z}}\left(\mathrm{m}^{-2} \cdot \mathrm{kg}^{-1}\right)$ & 18.7 & 19.4 & NS \\
\hline Leaf no./plant & 165 & 166 & NS \\
\hline Leaf temp. $\left({ }^{\circ} \mathrm{C}\right)$ & 27.4 & 28.6 & 0.0001 \\
\hline $\begin{array}{l}\text { Stomatal conductance } \\
\left(\mathrm{mol} \cdot \mathrm{m}^{-2} \cdot \mathrm{s}^{-1}\right)\end{array}$ & 0.51 & 0.65 & 0.001 \\
\hline
\end{tabular}

HortScience, Vol. 35(1), February 2000

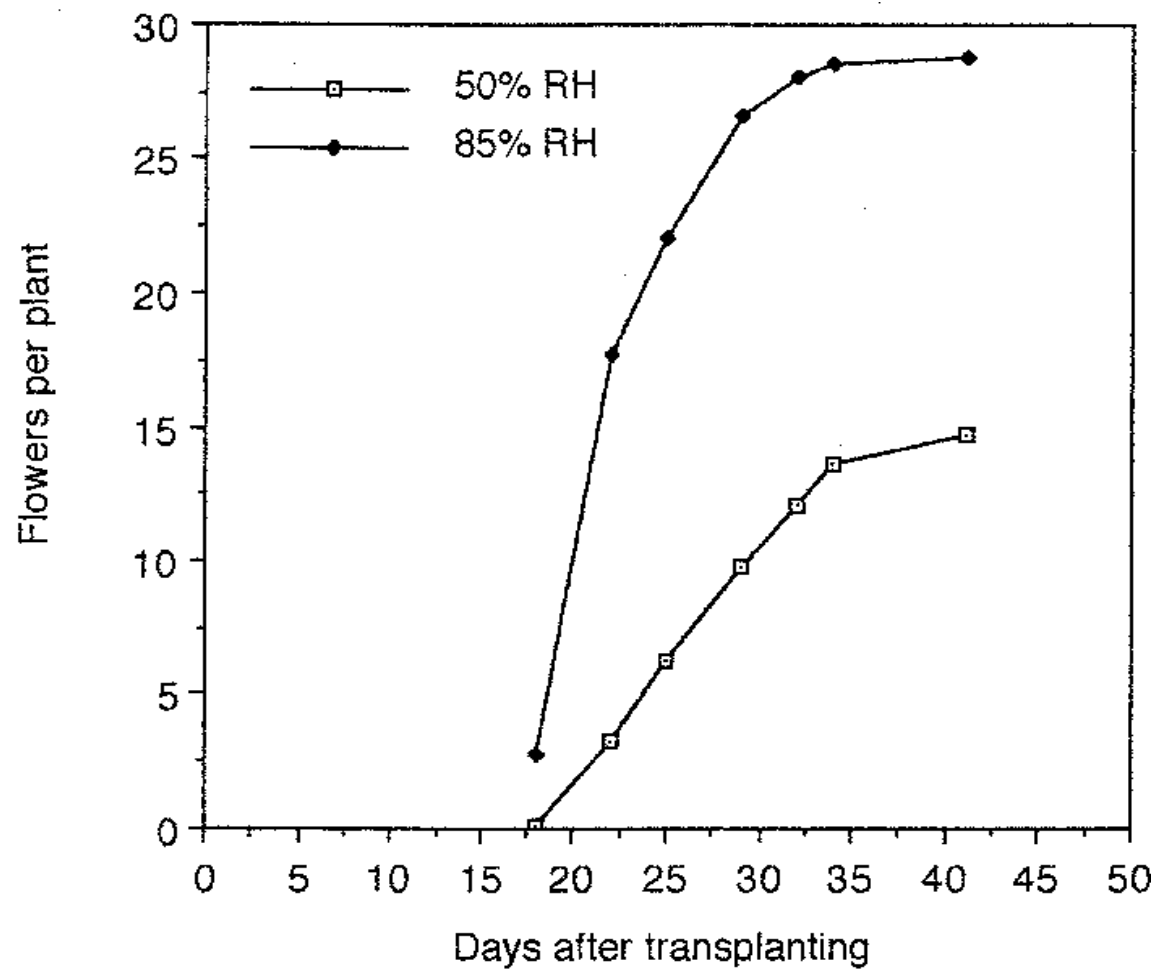

Fig. 1. Flowering rate of peanut plants at two relative humidities.

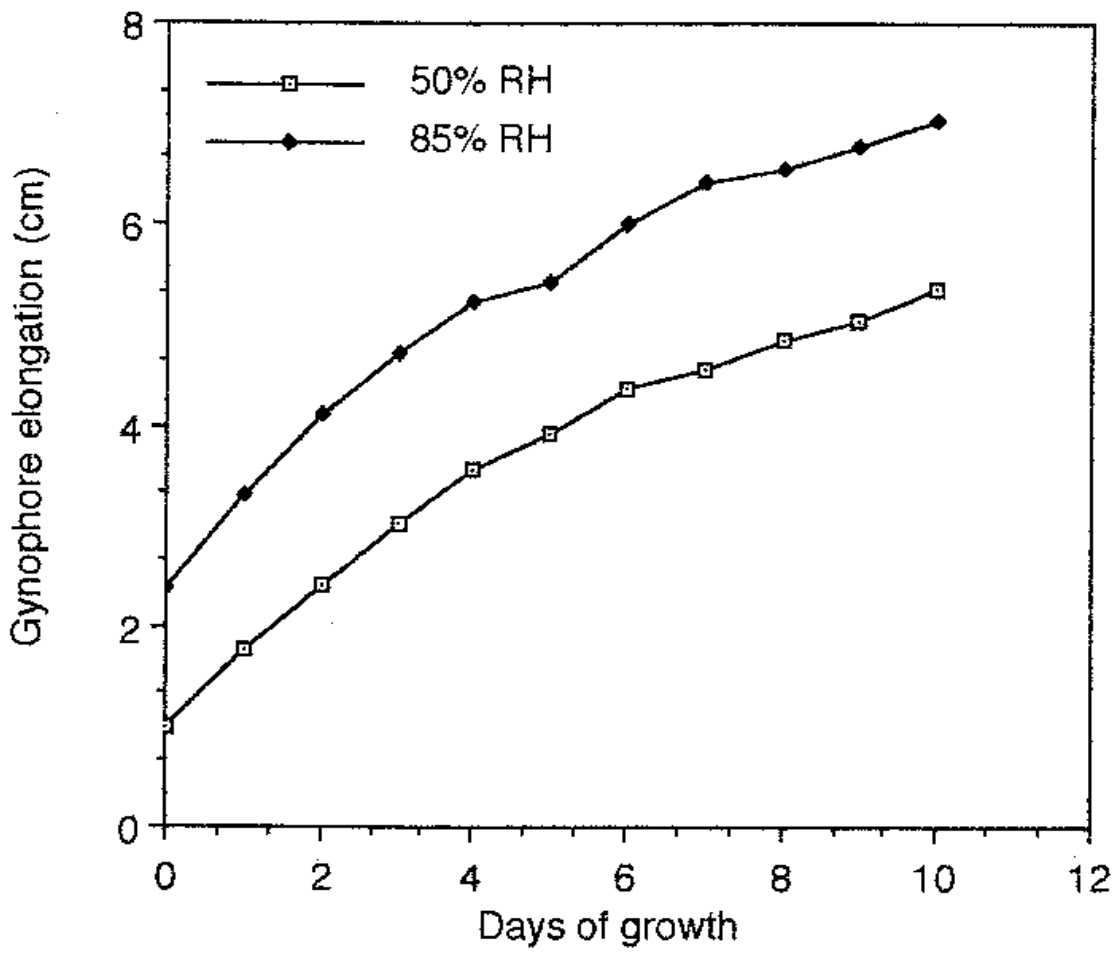

Fig. 2. Gynophore elongation of peanut at two relative humidities.

a 14- to 15-d period after flowering commenced. The rate of gynophore elongation was greater for plants grown at $85 \%$ RH (Fig. 2).

Our findings are consistent with data reported for several other plant species (Hoffman, 1979), including potato (Solanum tuberosum L.) (Wheeler et al., 1989), sweetpotato [Ipomoea batatas (L.) Lam] (Mortley at al., 1994), and apple (Malus $\times$ domestica Borkh.) (Tromp,
1996). Potato and sweetpotato have been selected by NASA for its ALS program. However, our data do not agree with those reported for red kidney bean (Phaseolus vulgaris L.) (O'Leary and Knecht, 1971), in which RH within the range of 35 to $100 \%$ had no significant effect on growth and yield, probably because the availability of water to the plants was not limiting. 
Two hypotheses offer partial explanations for the increased growth of plants under high RH. First, increased stomatal conductance may have enhanced $\mathrm{CO}_{2}$ uptake, ultimately influencing photosynthesis (Slavik, 1973). Second, high RH could have increased cell enlargement, providing a larger leaf surface area for light absorption (Hoffman et al., 1971). The data from this study indicate that both stomatal conductance and leaf surfaces were increased at the higher $\mathrm{RH}$.

The higher harvest index (Table 1) in plants grown at $85 \% \mathrm{RH}$ suggests that the relative distribution of photosynthates to seeds was greater.

The sequence of events influencing the response of stomates to $\mathrm{RH}$ is uncertain. Meinzer et al. (1997) reported that the observed response to humidity is stomatal sensing of the epidermal or cuticular transpiration rate rather than the bulk leaf or stomatal transpiration rate. In contrast, Bunce (1998) has suggested that because abscisic acid sensitizes stomates to $\mathrm{CO}_{2}$, it is probably involved in the response of stomatal conductance to humidity.

The greater rates of flowering and gynophore growth among plants exposed to $85 \%$ RH (Figs. 1 and 2) are consistent with data reported by Lee et al. (1972). They reported that high RH (95\%) increased ethylene concentration in developing gynophores, with a concomitant increase in gibberellins that stimulated their growth. This increase in ethylene/ gibberellins could partly explain the enhanced growth rate at high RH in our study.
The results from this study suggest a possible benefit of raising RH levels for increasing the yield of peanut in an ALS program. However, in a mixed cropping system typical of an ALS, a high RH might be difficult to maintain, particularly with temperature requirements being different for each crop.

\section{Literature Cited}

Black, C.R. and G.R. Squire. 1979. Effects of atmospheric saturation deficit on the stomatal conductance of pearl millet (Pennisetum typhoides S. and H.) and groundnut (Arachis hypogaea L.). J. Expt. Bot. 118:935-945.

Bunce, J.A. 1998. Effects of humidity on short-term responses of stomatal conductance to an increase in carbon dioxide concentration. Plant, Cell and Environ. 21:115-120.

Davidson, J.I., Jr., T.B. Whittaker, and J.W. Dickens, 1982. Grading, cleaning, storage, shelling, and marketing of peanuts in the United States, $\mathrm{p}$. 501-620. In: H.E. Pattee and C.T. Young (eds.). Peanut science and technology. Amer. Peanut Res. and Educ. Soc. (APRES), Yoakum, Tex.

Ford, M.A. and G.N. Thorne. 1973. Effects of atmospheric humidity on plant growth. Ann. Bot. 38:441-452.

Hoagland, D.R. and D.I. Arnon. 1950. The waterculture method for growing plants without soil. Calif. Agr. Expt. Sta. Circ. 347.

Hoffman, G.J. 1979. Humidity, p. 141-171. In T.W. Tibbitts and T.T. Kozlowsky (eds.). Controlled environment guidelines for plant research. Academic, New York.

Hoffman, G.J., S.L. Rawlins, M.J. Garber, and E.M. Cullen. 1971. Water relations and growth of cotton as influenced by salinity and relative humidity. Agron. J. 63:822-826.

Lee, T.A., D.L. Ketring, and R.D. Powell. 1972. Flowering and growth response of peanut plants (Arachis hypogaea L. var. Starr) at two levels of relative humidity. Plant Physiol. 49:190-193.

Meinzer, F.C., T.M. Hinckley, and R. Ceulemans. 1997. Apparent responses of stomata to transpiration and humidity in a hybrid poplar canopy. Plant, Cell and Environ. 20:1301-1306.

Mortley, D.G., C.K. Bonsi, P.A. Loretan, W.A. Hill, and C.E. Morris. 1994. Relative humidity influences yield, edible biomass, and linear growth rate of sweetpotato. HortScience 29:609 610.

O'Leary, J.W. and G.N. Knecht. 1971. The effect of relative humidity on growth, yield, and water consumption of bean plants. J. Amer. Soc. Hort. Sci. 96:263-265.

Rucker, K.S., C.K. Kvien, G. Vellidis, N.S. Hill, and J.K. Sharpe. 1994. A visual method of determining maturity of shelled peanuts. Peanut Sci. 21:143-146.

Slavik, B. 1973. Transpiration resistance in leaves of maize grown in humid and dry air, p. 267269. In: R.O. Slayter (ed.). Plant response to climatic factors. UNESCO, Place de Fontenay, Paris.

Tibbitts, T.W. and G. Bottenberg. 1976. Growth of lettuce under controlled humidity levels. J. Amer. Soc. Hort. Sci. 101:70-73.

Tromp, J. 1996. Sylleptic shoot formation in young apple trees exposed to various soil temperature and air humidity regimes in three successive periods of the growing season. Ann. Bot. 77:6370.

Wheeler, R.M., T.W. Tibbitts, and A.H. Fitzpatrick. 1989. Potato growth in response to relative humidity. HortScience 24:482-484. 